\title{
Um estrangeiro de mim mesmo a identidade fragmentada em Berkeley em Bellagio, de João Gilberto Noll
}

\author{
Ânderson Martins Pereira \\ Ariane Avila Neto de Farias ${ }^{2}$
}

\begin{abstract}
Resumo: A literatura contemporânea vem expondo cada vez mais o "eu", trazendo à tona a figura externa do autor, que há muito havia sido morta por pesquisadores estruturalistas. Para alguns teóricos, tais textos vão ser denominados "autoficção". O presente trabalho busca discutir o romance de João Gilberto Noll, Berkeley em Bellagio (2002) a partir das noções acerca desse sujeito fragmentado apresentadas pelo gênero autoficcional. Pesquisadores como Diana Klinger defendem que, ao trazer relatos em primeira pessoa, a autoficção, ao mesmo tempo em que parece atender a demanda de um sujeito narcisista, demonstra o desmoronamento da concepção de um sujeito pleno. Tomando por pressuposto a relação da dicotomia "eu" e "outro", acredita-se que, para a obra aqui analisada, a única forma de se sentir inteiro é abraçar o outro e renegar uma visão fixa de si mesmo.
\end{abstract}

Palavras-chave: autoficção; identidade contemporânea; escrita de si

\section{A foreigner of myself: a fragmented identity in Berkeley Em Bellagio, by João Gilberto Noll}

\begin{abstract}
Contemporary literature is exposing the "I" by revealing the external figure of the author, "killed" long ago by structuralist researchers. For some theorists, these texts would be called "autofiction". The present paper aims to discuss the novel of João Gilberto Noll, Berkeley in Bellagio (2002), based on the notions on this fragmented subject presented by the autofictional genre. Researchers like Diana Klinger argue that by bringing first-person accounts, the autofiction shows, at the same time, the demand of a narcissist subject and the collapse of the subject as an entire being. Taking into account this dichotomy between the "I" and the "other", we believe that, for the work analyzed here, the only way to become entire is to embrace the other and to deny a fixed view of oneself.
\end{abstract}

Keywords: autofiction; contemporary identity; writing the self

\section{Introducãa}

A literatura de hoje, não diferente da de outros tempos, vai ao encontro das necessidades das sociedades. Em uma época de completa exposição, os realities shows e as revistas de fofocas comprovam tal teoria, o sujeito está em foco. Como resultado disso, temos uma grande demanda de textos que expõem um "eu" e escrevem sobre si. Entretanto, nunca esse indivíduo esteve tão estilhaçado como agora. A busca pela atenção e o falar de si apresentam um sujeito perdido entre o que é e o que não é real. Isto posto, o objetivo do presente trabalho é propor uma análise do personagem central, Joao, do livro Berkeley em Bellagio (2002) do escritor gaúcho, João Gilberto Noll, texto que traz à luz os jogos entre o real e o ficcional e a construção de personagens que parecem perdidos em vista da velocidade do mundo moderno. Com o intuito de fomentar uma discussão em torno do modo em que se dá a inserção do sujeito em um mundo caracterizado pela fragmentação identitária, assumiremos aqui que a sociedade contemporânea traz consigo um homem narcisista, solitário e com uma identidade esfacelada, muito bem

\footnotetext{
${ }^{1}$ Mestrando em Letras, área de concentração Literatura Comparada, pela Universidade Federal de Pelotas. E-mail: andersonmartinsp@gmail.com

${ }^{2}$ Mestranda em Letras, área de concentração Literatura Comparada, pela Universidade Federal de Pelotas. E-mail: arianenetof@gmail.com
} 
retratado pela literatura autoficcional. Para tanto, o artigo baseia-se nos estudos de teóricos que discorrem acerca de conceitos relativos à construção da identidade e à autoficção tais como Trefzger e Diana Klinger. Outros autores serão usados para a discussão do espaço ocupado pelo autor nas linhas da literatura contemporânea, dentre eles pode-se salientar a discussão feita por Antoine Compagnon (2012) no livro Demônio da Teoria: literatura e senso comum.

No que concerne a discussão acerca da identidade, o conceito de performancer será importante para a análise literária do presente trabalho. Para isso, partiremos da ideia assumida pela teórica Diana Klinger de que a autoficção estaria inscrita "no coração do paradoxo [...]: entre o desejo narcisista de falar de si e o reconhecimento da impossibilidade de exprimir uma 'verdade' na escrita" (KLINGER, 2012, p. 22). Desta forma, a pesquisadora defende a ideia de que o autor, ao colocar-se no texto, faz de si uma espécie de perfomancer, conceito calcado a partir da teoria de Judith Butler - da verdade e da ficção, moldando sua vida como demiurgo de si mesmo.

À vista disso, Klinger defende que a autoficção seria marcada pelo retorno do autor morto pelos estruturalistas. Nas palavras da teórica, "o autor retorna não como garantia última da verdade empírica e sim apenas como provocação, na forma de um jogo que brinca com a noção do sujeito real" (KLINGER, 2012, p. 44). Dessa maneira, o autor tem o seu retorno caracterizado pela não detenção da autoridade sobre o texto, não podendo mais o leitor confiar nem no narrador nem no autor. Para Trefzger, "a autoficção assomaria não como ratificadora desse narcisismo elevado ao paroxismo, mas como problematizadora da constituição do sujeito inteiriço numa época, a nossa, que investe espetacularmente na proliferação de mitos" (TREFZGER, 2013, p. 3). Corroborando com tais ideias Tânia Pellegrini (1999) assinala que "nunca a imagem do escritor foi tão importante: veiculada pela imprensa e em menor escala pela mídia, chega a substituir a importância da própria obra" (PELLEGRINI, 1999, p. 173).

Sobre a figura do autor, o teórico Antoine Compagnon (2012), ao refletir sobre fatores universais analisados pela teoria da literatura e os critérios utilizados para uma melhor interpretação dos textos literários, identifica a presença de duas diferentes correntes: a primeira, denominada tese intencionalista que justifica-se pela intenção do autor como o "critério pedagógico ou acadêmico tradicional para estabelecer-se o sentido ao literário" (COMPAGNON, 2012, p. 49); já a segunda, a anti-intencionalista, justificar-se-ia pela denúncia do uso da intenção do autor como determinante do significado de uma narrativa, tendo em vista que "o sentido de uma obra não é, necessariamente, idêntica à intenção do autor e é mesmo provável que não o seja" (COMPAGNON, 2012, p. 81).

Ao considerarmos as reflexões de Compagnon, observamos que, atualmente, no que se refere ao terreno das narrativas pertencentes à categoria de texto de escrita de si, há uma verdadeira dissolução das fronteiras entre essas duas teses, posto que as produções literárias passaram a retratar temáticas complexas e discursos situados em um "entre-lugar", ou seja, detendo traços tanto da corrente intencionalista como o da anti-intencionalista.

Nessa esteira, Berkeley em Bellagio estaria inscrito nesse encontro dos dois polos teorizados por Compagnon. Também ao encontro do defendido por Trefzger e Klinger, tal texto pode ser localizado nesse percurso de reflexões acerca da essência de um "eu" pautado pelo narcisismo contemporâneo, trazendo, pois, para discussão a problemática do quanto o autor pode esconder e mostrar de si mesmo ao escrever. Assim, o escritor gaúcho parece ir ao encontro da literatura de outros escritores brasileiros como Silviano Santiago em $O$ falso mentiroso, Chico 
Buarque em $O$ irmão alemão, Critovão Tezza em $O$ filho Eterno, cujos textos também atualizam os limites da autoficção. Contudo, a escolha de Noll se dá pelo fato de entendermos que a obra supracitada do autor, provoca-nos ao nos depararmos com um eu performático, que ao dar vasão a si e a sua solidão, faz com que as fronteiras entre o real e o ficcional pereçam. Em Berkeley em Bellagio, vida e ficção se entrecruzam, criando uma narrativa na qual nada poderá ser mostrado sem um disfarce, sem um recuo, sendo isso transmitido a cada página; tanto o autor quanto seu narrador parecem tomados, ansiosos em comunicar, gritar algo. Temos um sujeito que em meio a solidão cotidiana, quer ser um outro. Em uma sociedade onde a perfeição é vendida a todo o momento pela televisão, quem não quer ser um outro?

Nessa perspectiva, Trefzger pontua que:

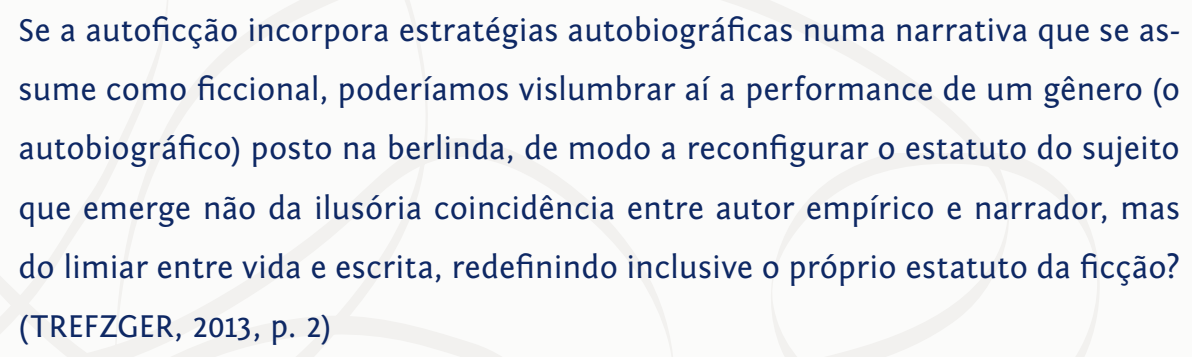

A autora evidencia a autoficção sediada em um entre-lugar e, desta forma, questiona a legitimação dos polos ficcionais e reais, inferindo-se, assim, que a autoficção oferece uma releitura sobre o lugar não só da autobiografia, mas também da ficção em si. Nestes textos, o "eu" é posto em destaque, mas suas relações com o "outro" não são menos evidentes, elas se instauram pela dificuldade do "eu" de dar vazão à verdade de si mesmo e de encontrar essa verdade. Sob este viés, as relações de um "eu" incompleto com o "outro", também fragmentado, o auxiliam a lidar consigo mesmo.

Nas palavras da pesquisadora, o "diálogo com a espetacularização, que abrange um olhar crítico sobre 'a superficialidade contemporânea', incide diretamente no questionamento do sujeito pleno performando sua imprópria constituição totalizante" (TREFZGER, 2013, p. 4). Desta maneira, a autoficção seria então, um gênero crítico que expõe, por exemplo, o confronto do homem moderno com questões identitárias, colocando-o em face de diversos conflitos, entre eles o processo de formação de sua identidade cultural diante do mundo, e as fronteiras cada vez menores dos conceitos de cultura, linguagem, raça, etnia e religião. Hoje sabemos que a identidade e sua construção não dependem de uma simples identificação com específico grupo social, cultura ou causa, mas que está vinculada à conjuntura, às relações sociais, materiais e simbólicas e a padrões vividos.

Em Berkeley em Bellagio nos é apresentado um indivíduo que não apenas brinca com as fronteiras entre o real e o fictício, mas que as desconhecem. É importante pontuar que Berkeley em Bellagio não é o único trabalho de Noll que pode ser categorizado como autoficção. Em 2004, é lançado o livro Lorde. No primeiro, como mencionado, Noll nos apresenta o escritor chamado Joao, brasileiro e professor da Universidade de Berkeley nos Estados Unidos. A convite de uma fundação norte-americana, Joao, que deverá escrever um romance, vai para Bellagio, na Itália, onde passa a morar em uma residência de escritores. Já em Lorde, novamente temos um escritor, esse vai a Londres a convite de uma instituição britânica. 
De modo geral, a obra do escritor constrói personagens fragmentados e "seja qual for o livro, o protagonista é invariavelmente, um ser errante [...] que ao buscar o exílio, encontra cárceres renovados." (COSTA PINTO, 2004, p. 118-119). Em ambas as obras estes protagonistas não representam uma cisão com os demais personagens da obra de Noll, mas referenciam a todo o momento a pessoa do autor. Esta relação pode ser exemplificada pela homonímia entre autor, narrador, personagem tanto em Berkeley em Bellagio quanto em Lorde. Lembremos que para Philippe Gasparini, a autoficção seria "uma narrativa baseada na homonímia do autor, do narrador e do herói, mas que apresentava um desenvolvimento que se projetava em situações imaginárias" (NORONHA, 2014, p. 140). Assim, Joao é o nome escolhido por João Gilberto Noll para dar vida a uma personagem despedaçada.

Berkeley em Bellagio é o primeiro romance em que Noll opta por um viés autoficcional. A situação vivida pela personagem do livro encontra a realidade de Noll ao remontar ao período, final da década de noventa, em que o escritor João Gilberto Noll trabalhou como professor de Cultura Brasileira junto à Universidade da Califórnia (UCLA), em Berkeley. Logo no princípio do primeiro e único parágrafo do romance, o narrador indica tais circunstâncias:

\footnotetext{
Ele não falava inglês. Quando deu seu primeiro passeio pelo campus de Berkeley, viu não estar motivado. Saberia voltar atrás? Não se arrependeria ao ter de mendigar de novo em seu país de origem? Fingir que não pedia pedindo refeições, ou a casa de veraneio de um amigo em pleno inverno para escrever um novo livro - ah, quando os pinguins chegam à costa daquele extremo sul do Brasil, o vento passa destelhando e uma voz noturna chama, chama pelo desaparecido infante... Ele não falava inglês e se perguntava se algum dia arranjaria mais disposição para aprender mais uma língua além de seu português viciado, com cujas palavras já não conseguia dizer metade do que alcançava tempos atrás (NOLL, 2003, p. 09).
}

Temos um escritor brasileiro que nada sabe sobre a língua do país que visita e, consequentemente, não consegue comunicar-se. A experiência narrada por Joao é muito próxima a do escritor João Gilberto Noll. O personagem divide com Noll a necessidade de sair de sua terra natal, já que ambos não conseguiriam se sustentar como escritores no Brasil da época. Joao se encontra em uma terra que não a sua e busca a todo o momento se (re)significar e se adequar a uma língua e a uma cultura do "outro". Sobre a experiência, o autor, em entrevista dada a Claudia Nina, para o Jornal do Brasil (2002), declara a similitude de suas vivências com o personagem Joao. Ele pontua que ao chegar ao passar pela experiência de Berkeley sentiu que escreveria sobre o estranhamento que conhecera ao estar em um lugar estrangeiro. Todavia, a narração dessa experiência não é a de um texto que se compromete com seu relato autobiográfico, mas uma narrativa que emerge do biográfico para construir-se como autoficção. O autor ainda salienta que,

Os dados biográficos de Berkeley em Bellagio estão mais do que nunca presentes neste livro e vêm antes de tudo de o que a geografia pode dar. E, para quem ama o dom da visão, a geografia é tremendamente pródiga para a criação. Não são, 
portanto, os fatos vividos que eu retrato com mais empenho. São essas paisagens estrangeiras que nos dão a graça da transfiguração do mundo e não a observância estrita de uma cor local já desgastada pela nossa desatenção rotineira. (NOLL; NINA, 2002, online)

É possível depreender que o autor se descompromete com a legitimidade de suas experiências para dar vazão a um ideal, também vivenciado de identidade cambiante e fragmentada posto o contato o "outro". Logo, as vivências narradas corroborarão para a exposição desta relação. Outros trechos conectam auto/narrador/personagem:

\begin{abstract}
[...] quem era mesmo esse homem nascido em abril em Porto Alegre, no hospital Beneficência Portuguesa, às seis horas da manhã, criado no bairro Floresta, sem poder imaginar que um dia estaria aqui nesse castelo, ao norte da Itália, perto de Milão, na chamada - jocosamente ou com sarcasmo - "Catedral” americana; quem era esse homem que já se cansava da noite tão cedo, louco pra dormir, sonhar, regenerar-se para ao longo do dia seguinte cair no mesmo enfado [...] (NOLL, 2002, p. 27).
\end{abstract}

[...] só não lembro a data em que cheguei, quando retornarei à Porto Alegre, para as águas barrentas do Guaíba, para as minhas caminhadas a partir da Usina do Gasômetro até a Praça da Matriz [...] (NOLL, 2002, p. 59).

Autor e personagem não são confiáveis; Joao não lembra de lugares, nomes e não recorda sua língua, transitando por lugares em que não consegue se comunicar. Joao é e não é João, pois o "eu" escritor já passara pelas situações narradas e outras além dessas. Entretanto, é perceptível um imbricamento nestas duas personas, já que joao vivencia as experiências que para João fazem parte de seu passado e esta sobreposição de personas é sentida pelos problemas de memória no personagem, o qual entra em conformidade com a inabilidade ou a escolha de João ao performar essa narrativa.

\title{
"Joao, Joao, treinando um til com o dedo pelo ar, a repetir Joav, Joao"3: uma identidade em mil nedaços
}

Não muito diferente dos demais trabalhos do escritor, Berkeley se passa em lugares "esvaziados de progressão e tempo, não estando dotados de nenhuma função libertadora, edificante ou pedagógica ou oferecendo a João nenhuma forma de enriquecimento" (KLINGER, 2012, p. 52). Como bem explicitado na obra, Joao é "alguém que nada faz, que nada tem, nem ao seu próprio corpo" (NOLL, 2002, p. 52). A protagonista de Berkeley

[...]reflete a falta de consciência e o fracasso existencial do homem contemporâneo. Daí, em seus escritos, a recorrência de personagens, cujas identidades estão

\footnotetext{
${ }^{3}$ NOLL, 2002, p. 47
} 
sempre à deriva. Tratar-se-ia de sujeitos fragmentados e incapazes de estabelecer uma narrativa coerente do "eu", de dar significado e sentido a sua própria existência (OLIVEIRA, 2011, p. 02).

O romance, seguindo a linha de Noll de livros com poucas páginas e de linguagem concisa, é narrado tanto em primeira quanto em terceira pessoa, não apresentando divisão por capítulos. Em Berkeley, estamos diante de uma narrativa que se inscreve dentro de si mesma. Lembremos que ao personagem Joao é encomendado um romance, e esta encomenda assemelha-se ao romance que temos em mãos. Tal recurso parece ser recorrente na literatura contemporânea, pensemos em Divórcio do escritor Ricardo Lísias. No texto citado, o escritor questiona uma possível fronteira entre o real e o imaginário. Como pano de fundo temos a cidade de São Paulo, sua narração é feita em primeira pessoa e o enredo do romance está centralizado no fim dramático do curto casamento do narrador-protagonista Ricardo Lísias. Ao se levar em consideração a escolha do nome do protagonista da narrativa, a princípio o leitor é levado a conectar tudo o que é descrito na obra a uma identidade estabelecida entre o escritor, elemento extraliterário, e o pretenso narrador, ou seja, que o nome do autor é o mesmo do narrador e da protagonista.

Nas linhas da produção de Noll (ou seria de Joao?) somos guiados, por diferentes espaços, pelos pensamentos não lineares do mesmo, assim, o parágrafo que dá início ao texto, só terá fim na última página do romance. Não há uma sequência de fatos organizados cronologicamente e o que encontramos é uma mistura de experiências, lembranças e imaginações da personagem.

O romance tem seu início marcado pela narração de um acidente, ocorrido no Brasil, que acaba por afetar a memória da personagem, já em Berkeley. O leitor não tem acesso ao que aconteceu verdadeiramente. Tal situação fica em aberto durante toda a narrativa. O narrador não está ali para resolver problemas e não nos dá respostas. Os trechos a seguir demonstram o afirmado anteriormente, "Quem era ele afinal [...] De quem ele gostava, por quem se apaixonava? [...] ao falar, expressava não bem a forma daquilo que pensava ou sentia [...] (NOLL, 2002, p. 22,24).

No decorrer da narrativa, as incertezas do narrador/autor esbarram em um personagem que não se reconhece e, assim, temos acesso a diferentes versões de um acidente que o conduz a um processo de reconstrução de si, de sua própria identidade. O narrado é a apresentação de um "eu" perdido dentre as diferenças de um mundo sem fronteiras. João não nos apresenta um completo Joao, ele precisa de respostas tanto quanto o autor.

Ainda nas primeiras páginas descobrimos os sentimentos de incerteza e incompletude que perpassam a personagem central da trama. Isto pode ser recuperado na passagem: "Ele não falava inglês. Quando deu seu primeiro passeio pelo campus de Berkeley, viu não estar motivado? Saberia voltar atrás?" (NOLL, 2002, p. 09). Joao é um homem de meia-idade que se alimenta, a cada dia, da solidão, do sentimento de não-pertencimento, do silêncio e das suas lembranças do Brasil. Mesmo que a ida para ao exterior signifique certa trégua à penúria de sua vida brasileira, repleta de problemas financeiros, são suas brigas com os espaços físicos em que transita que muito refletem sua condição interior, seus conflitos.

Em Berkeley, a oportunidade de trabalho parece não o motivar, uma vez que entende seu papel de professor de Cultura Brasileira como sendo o de 
[...] um emissário de pérolas brasileiras que os alunos americanos pareciam receber com a efusão conveniente às melhores notas - para depois de formados poderem operar as mais produtivas relações internacionais para o país deles controlar melhor o cosmos. (NOLL, 2002, p. 14)

É ao caminhar pelas ruas de Berkeley que o escritor recorda o tortuoso caminho para retirada de seu visto. É nesse caminhar que este entende seu caráter de cidadão latino-americano, sofrendo com o estereótipo do imigrante.

Já em Bellagio, não é diferente. No que ele vai chamar de "exílio branco no conforto de universidades e fundações americanas" (NOLL, 2002, p. 43), a personagem mostra-se sem grandes disposições de convivência com os colegas, tanto por não dominar o idioma, este sempre um obstáculo para construção de laços em todos os lugares por onde o personagem passa, quanto pelo pouco em comum com os artistas. Assim, Berkeley em Bellagio transforma-se em um retrato pungente de um sujeito errante, sem referencial algum, procurando por um lugar em um mundo cada vez mais globalizado/sem fronteiras e também excludente.

Nesta perspectiva, o projeto autoficcional de Noll parece ir ao encontro do defendido por Trefzger. A autora, citando Evandro do Nascimento, afirma que:

\begin{abstract}
[...] esse eu múltiplo e impessoal, porém intransferível, não se confunde com nenhum narcisismo banal ou mortífero, pois o espelho está desde sempre partido. / não há como pular para "lá", o suposto outro lado do espelho, porque a folha de estanho rachou, derramando o conteúdo alucinatório do eu ideal. "lá" fica mesmo aqui, ali, raramente além. (NASCIMENTO apud TREFZGER, 2013, p. 03).
\end{abstract}

Joao, ao expor suas memórias fragmentadas, põe em xeque questões de identidade, não apenas do sujeito, mas da própria nacionalidade completamente perdida em tempos de globalização. O sujeito uno que já não mais existe. Vive-se um momento de crise identitária, de valores e de modelos de interpretação do real. Noll traz um sujeito e um mundo heterogêneos, formado de conceitos que ora se confluem em um mesmo sentido, ora divergem, caminhando em direções completamente opostas.

O texto do escritor gaúcho está em consonância com textos do teórico Stuart Hall, que afirma que a contemporaneidade é um tempo que carrega múltiplas possibilidades de leituras e interpretações, uma época conhecida pela fragmentação da noção do todo e que leva a uma consequente ascensão da pluralidade de experiências. Tanto para escritor quanto para narrador e personagem, o presente está além das certezas dos discursos, da ideia de unidade, da razão, da ruptura com a noção do permanente, do tempo, do espaço, tudo que era sólido perde sua forma para assumir outra, rompendo-se em pequenas frações, em uma eterna mutação, um período marcado por oscilações do saber. Tais fatos parecem validar também a impossível desconexão entre Joao e João, ambos são uma construção múltipla de diferentes situações. Para Joao existir, é preciso que João exista. Um sente através do outro. Tal premissa pode ser sentida no trecho a seguir: "Sei com toda a certeza de que estou de novo no meu corpo e que ele dói, dói tudo o que tinha para doer, até que eu me levante [...] e depois nu diante do espelho me aperceba de que o meu corpo já cansou da dor" (NOLL, 2002, p. 62). 
O conjunto de mudanças estruturais de um tipo diferente, definidas por Hall, que no fim do século XX abalaram as noções de identidades culturais, garantia de um sujeito com localização "sólida", e também afetaram concepções internas de identidade individuais, de um sujeito integrado, são visualizadas na narrativa de Noll, onde encontramos um sujeito fragmentado e totalmente imprevisível. Joao personifica "o sujeito, previamente vivido como tendo uma identidade unificada e estável, está se tornando fragmentado; composto não de uma única, mas de várias identidades, algumas vezes contraditórias ou não resolvidas" (HALL, 2002, p. 12).

O excerto acima confirma que indivíduo contemporâneo encontra uma firmeza, ainda que paradoxal, acerca de sua própria crise identitária. Segundo Hall (2002, p.12), “a identidade, então, costura [...] o sujeito à estrutura". Dessa forma, pode-se dizer que o paradoxo nasce de um entorno que não mais dá conta do indivíduo multifacetado. Neste cenário, há uma emergência de identidades plurais e, por vezes, estas são contraditórias em decorrência desta pluralidade. A nova concepção do sujeito se caracteriza pelo provisório, variável e problemático, alguém como não tendo uma identidade fixa, essencial ou permanente.

Hall (2002 p. 13) ainda afirma que a identidade plenamente unificada, completa, segura e coerente é uma fantasia. Ao invés disso, à medida em que os sistemas de significação e representação cultural se multiplicam, somos confrontados por uma multiplicidade desconcertante e cambiante de identidades possíveis, com cada uma das quais poderíamos nos identificar - ao menos temporariamente.

O afirmado acima é percebido na obra de Noll. Para a protagonista de Berkeley em Bellagio, a identidade nunca é totalmente explicável e persiste como um fantasma que acompanha os seus pensamentos e experiências. Ela apresenta diversas situações onde se é possível evidenciar sua identidade fragmentada, onde a protagonista entende-se como outro. Uma delas refere-se ao seu papel de narrador que, alternando as vozes enunciativas entre a primeira e a terceira pessoa do singular, indaga-se a certa altura:

\footnotetext{
[...] e quem será esse homem aqui que já não se reconhece ao se surpreender de um golpe num imenso espelho ornado em volta de dourados arabescos, um senhor chegando à meia-idade? (NOLL, 2002, p. 29)
}

[...] e qual percepção eu poderia ter de mim mesmo naquele vão noturno que quase me engole num repente? Quem me responde, e já, se o fato de eu estar aqui andando pelo bosque em plena madrugada me confere alguma garantia de que eu não seja um outro que de fato sou, um estrangeiro de mim mesmo entre norte-americano (embora pisando em solo italiano)? Sou alguém que se desloca para me manter fixo? (NOLL, 2002, p. 36)

É no recorrente questionamento de sua própria identidade, no movimento incessante de indagar-se a si mesmo o que ou quem ele é, que o protagonista se torna outro para si mesmo. Sua condição de estrangeiro se insinua nessa capacidade de transformar-se, de construir novos sentidos sobre si mesmo, engajando-se em uma espécie de aventura do "Eu é um outro".

A fragmentação da identidade é vista também na relação fronteiriça entre o "eu" e os limiares do "outro". Em Berkeley em Bellagio estes limites são quase inexistentes, visto que a 
identidade do "eu" se encontra há muito esvanecida. "O fantasma de Berkeley está mesmo era lá dentro, prisioneiro na 'Catedral' da fundação já vazia de scholars. Entro no carro, divago que o ragazzo deve ser um mordomo daqueles bem fiéis, que acompanham a derrota do dono até o fim, isso! " (NOLL, 2002, p.76). Neste mesmo sentido esse excerto, retirado de Barkeley em Bellagio, demostra uma supervalorização do "outro" ligada ao espaço. Joao considera-se derrotado por voltar ao Brasil e a narrativa da cena pode ser comparada a um ritual fúnebre, no qual comparecem todos os personagens para testemunhar o futuro atroz que aguarda o protagonista.

Ainda em uma leitura do "outro" como figura utópica, em Berkeley em Bellagio pode-se destacar a língua do estrangeiro e seu status elevado. O personagem busca a todo momento adequar-se ao idioma, incluir o inglês e o italiano na sua narrativa e se considera burro por não conseguir falar em língua estrangeira, "quando acordo me vem de novo o inglês, sunny day, never mind, e todas as expressões em que eu antes tropeçava com veemente insistência sem saber por quê" (NOLL, 2002, p.55).

A passagem corresponde a um momento onde o personagem maravilha-se por estar, de repente, falando inglês. Ainda assim, esta aquisição do "outro" não é completa e pode-se encorajar tal leitura com base nas palavras utilizadas no excerto acima. Tais palavras existem separadamente, mas tem um sentido único estando juntas, tendo a última a grafia de ambas em uma única palavra - o que é sinalizado pelo uso das vírgulas - desta forma ele se apropria de palavras como never e mind, mas não de nevermind. Esta brincadeira com as palavras pode ser vista também como a incapacidade de dizer "não importa" em inglês, visto que para o personagem a língua é de extrema importância, sendo um caminho para chegar a este "outro".

Em Berkeley em Bellagio o reconhecimento da necessidade da relação construtiva do "eu" e do "outro" é sentido pelo narrador do romance:

\footnotetext{
Não fosse um homem ter despejado seu gozo dentro de uma mulher, não fosse isso o filho que ele era não estaria aqui nem haveria para sua escuta o Liszt que ele ouvia agora, nada, só a paz dessa floresta de Bellagio, o assovio do vento intermitente do vento noturno -, não haveria ele nesse corpo perpetuamente redivivo enquanto houvesse pensamento, fábula, história, ele pensou coçando-se ao infinito. (NOLL, 2002, p.36).
}

Ainda que o protagonista se utilize de exemplos metafóricos materiais, pode-se depreender que sem a união de um "eu" com um "outro" ou de uma mulher com um homem, não há vida e há uma inviabilização do ser e das possibilidades de relação deste. Desta maneira, a relação entre ambas estruturas é paradoxal, pois ao mesmo tempo em que cria, desconstrói, e o modifica, como o personagem vinha se modificando ao som de Liszt tocado pelo pianista.

O título é índice da marcação ideológica desta relação na obra Berkeley em Bellagio. Neste campo cabe atermo-nos a preposição "em", pois ela redimensiona estes espaços como se um lugar estivesse dentro do outro e o (re)constituísse. Essa leitura é interessante pela ausência, visto faltar no título um dos lugares vistos no romance, o Brasil. Contudo, o elemento de urdidura entre estes espaços é o narrador, que traz características também do espaço brasileiro. Assim, o Brasil está em Berkeley e em Bellagio personificado nas experiências do narrador, mas esses espaços do título lhe são ambos estrangeiros. Temos então no título dois "outros" que 
são estrangeiros ao narrador, mostrando que o "outro" se constitui a partir do "eu", visto que a aproximação entre as duas cidades somente é possível pelo contato do "eu" de Joao.

A discussão acerca do "eu", constituído de uma memória de si é trabalhada em Berkeley em Bellagio. Vejamos o trecho a seguir,

me enrosco todo de novo sobre o banco de pedra da antiga Roma, quisera ser uma ave ferida bem na asa, e aqui ficar até que alguém viesse para cuidar de mim porque já nem sei que faço nem que digo, já nem sei se sonho (NOLL, 2002, p. 44).

Neste excerto, há a imagem da ave ferida que perde sua habilidade mais premente que é o voo e, portanto, inspira cuidados. Esta metáfora cabe ao personagem que inspira cuidados não por ter deixado de voar, mas por ter perdido a capacidade de reconhecer-se enquanto sujeito destacado dos demais. O fato de já não saber o que faz ou o que diz, ou o que sonha, remete-nos à necessidade de o personagem de encontrar algo de seu nestas atividades e que não estejam maculados pelo desejo de outrem.

Esta passagem torna-se paradoxal por exercer o desejo de uma pureza do "eu", mas necessitando da figura do "outro" para tal, como se outro ser pudesse cuidar das feridas do narrador e devolvê-lo a um estado de normalidade. Dessa forma, pode-se aventar se tal bem-estar gerado pelo cuidado não estaria justamente no contato e na troca de ambas as identidades e na destituição de tais desejos de pureza pelo "eu".

A busca do passado para a restituição da identidade, traz consigo a problemática do tempo. Como dito, o narrador se perde no encadeamento dos tempos verbais, tal altercação é considerada por Doubrovsky como normal e sintomática do gênero, "ora, duas outras considerações conferem ao texto um estatuto oposto. A enunciação e o enunciado não estão separados por um necessário intervalo, mas são simultâneos. 'Viver ou contar', dizia Sartre em 'A náusea'” (DOUBROVSKY, 2014, p. 116). Podemos ver tais características no excerto abaixo:

\footnotetext{
Se eu for visitá-la todos os domingos à tardinha, essa menina teria um novo amigo que pegaria o ônibus no centro da cidade, desceria na parada próximo à casa dela, atravessaria a várzea onde garotos jogam bola com enormes palavrões, bateria palmas ao chegar à cerca de sua casa, não há cão para me assustar, venho com notícias de que consegui vaga para a criança numa escola pública bem perto, a dez minuto desse endereço, amanhã virei busca-las, ela e sua mãe que apresentarei à professora (...) a mãe me agradece misturando o português com a sua língua meio exasperada, o dia quente, azul, eu me despeço da mulher toda de preto. (NOLL, 2002, p. 80 , grifo nosso)
}

Na passagem acima, é possível lermos também a falta de paralelismos verbais como a existência de um "eu" identitário do passado sendo distinto do atual e considerado mais inteiro; contudo, tal ideia é perpassada pelo "eu" fragmentado do autor. Tal leitura traz novamente a análise da noção de utopia e ideologia, sendo o "outro" neste contexto o próprio "eu" do narrador, fronte ao "eu" narrado. 
Percebemos que, na narrativa, tempos verbais imbricam-se, pessoas se misturam, e há também a confusão do personagem ao narrar uma história em que esteve envolvido. Logo no início, ele faz uso de verbos no futuro do pretérito "teria", "desceria" fazendo menção a situações que poderiam ter acontecido, algo do/no passado; mais adiante ele já situa alguns verbos no futuro do presente "virei", "apresentarei" mencionando, assim, fatos que irão acontecer; no final, a personagem ao usar "agradece" e "despeço", situando o narrado no presente, como se agora tivesse certeza do que narra, algo aconteceu, real. Dessa maneira, são criados jogos de imagens e possibilidades que demonstram a fluidez da narrativa, a fluidez do "eu" que narra, demonstrando assim, a fusão entre o sonho e a realidade, a condição do sujeito contemporâneo em eterna construção, sujeito errante e sem referencialidades.

A partir do exposto a tensão entre o "eu" e o "outro" pode ser tida como ponto central na obra de Noll. Contudo, não é apenas a tensão entre ambas na busca de certa legitimação que está descrita no romance, mas também a confluência sadia entre os extremos. Essa confluência se faz perceber pelo sexo, que é um tema muito presente na obra, pois, é nele que a relação de troca se torna simbiótica e que o protagonista do romance pode partilhar de uma vivência transcendental onde o limite entre o "eu" e o "outro" são destruídos.

Outro momento no qual percebemos o estilhaçamento de sua identidade é na maneira como a personagem se remete a Léo, seu companheiro que ficou no Brasil. As sensações que Joao descreve referentes ao ato sexual são ambíguas, podendo ser interpretadas também como a relação que é desenvolvida pelo narrador com sua identidade. $O$ texto a seguir demonstra como as memórias de Léo são recebidas, assim como a subjetividade é entendida pela protagonista: "um fluído indeciso, de repente inundando-o todo, sumindo de repente, sempre escorregando de sua própria mão que pretendia por vezes segui-lo, tocá-lo, fechá-lo entre os dedos - prendê-lo na boca" (NOLL, 2002, p. 09).

A partir do trecho citado acima nos remetemos a ideia de vida líquida trazida pelo teórico Zygmunt Bauman:

\footnotetext{
A vida líquida e a modernidade líquida estão intimamente ligadas. A vida líquida é uma forma de vida que tende a ser levada à frente numa sociedade líquido-moderna. Líquido-moderna é uma sociedade em que as condições sob as quais agem seus membros mudam em um tempo muito curto do que aquele necessário para a consolidação, em hábitos e rotinas, das formas de agir. A liquidez da vida e da sociedade se alimentam e se revigoram mutuamente. (BAUMAN, 2001, p. 7)
}

A identidade líquida escorrega das mãos do narrador, é indiscutível. Tal metáfora vai de encontro a uma narrativa cujos sentimentos escorregam entre os dedos e boca, estes não serão desvendados. Joao é incapaz de traduzir sua subjetividade. Se tomarmos a noção de estrangeiro defendida por Kristeva de que este "é a face escondida de nossa identidade, o espaço que arruína nossa permanência, o tempo onde se deteriora a compreensão e a simpatia" (KRISTEVA, 1994, p. 9), podemos afirmar que Joao é estrangeiro de si mesmo. Frente às mudanças de sua vida, ele perde-se, não se reconhece mais. Suas lembranças vão se perdendo.

Durante todo o desenvolver do enredo novas angústias da personagem nos são apresentadas. A protagonista de Noll em sua fragmentação, na busca de si e de outros, tem seu caminho 
cruzado por pessoas desconhecidas e assim, seu "eu" vai sendo formado por "outras identidades”, não só culturais, mas individuais. Tal fator é observado por Hall (2002, p. 17), que descreve o sujeito como sendo "formado e modificado num diálogo contínuo com os mundos culturais 'exteriores' e as identidades que esses mundos oferecem".

No final do romance, ao regressar para Porto Alegre, Joao percebe que perdeu sua língua materna, volta sem falar o português, sem conseguir comunicar-se em seu próprio país, como mostra o excerto a seguir: "era um brasileiro a pensar em inglês o tempo todo, eu era outro em mim, não tinha importância -, quando chegasse a Porto Alegre iria para um curso de português para estrangeiros [...]" (NOLL, 2002, p. 82-83). Noll teme ter perdido a própria língua materna no processo da aquisição de outra. Esta relação com as línguas pode ser considerada uma metáfora para com a relação do "eu" com o "outro", como pode ser observado no excerto a seguir: "a primeira coisa que fiz no aeroporto de Porto Alegre foi deixar a bagagem num guarda-volumes e me dirigir ao balcão de informações e perguntar onde podia encontrar na cidade algum curso de português para estrangeiros" (NOLL, 2002, p. 85). Quando estas relações entre interlíngua ou entre ele e os demais personagens acontecem, o narrador perde o limite de suas fronteiras, sejam elas linguísticas ou identitárias.

Como já mencionado, os limites das identidades nacionais são postos em questão pelo mundo moderno. O que faz de Joao brasileiro? Sua língua? A língua que acaba de perder? A personagem parece ser esse encontro de nacionalidades, a confluência de vários "eus". A língua incorpora o signo da fronteira. Perder a língua pátria/materna no regresso é para o narrador demonstração de que, também neste lugar, ele se tornou estrangeiro.

Ainda no final da narrativa, ao reencontrar Léo, Joao parece, mesmo sem saber até quando, encontrar em um "outro" a possibilidade de reconstituição de sua identidade quebrada, de um encontro de si mesmo. Entretanto, no decorrer do romance, mesmo depois de seu regresso, suas histórias são contadas de diferentes maneiras por uma personagem esfacelada em mil pedaços e com memórias traiçoeiras que confundem imaginação e real, comprovando a inviabilidade de tal reconstrução.

A consequência da incapacidade de distinção entre vivido e não vivido pela personagem, é a de termos um romance que não possui um final. Com suas últimas linhas que mantém em aberto e expõem a fratura do sujeito, um eterno quebra-cabeça em que peças são perdidas, não se encaixam. Não temos respostas, não podemos tê-las. A construção da identidade é um processo inacabado e inalcançável.

\section{Consideraçōes Finais}

Sabemos, como já definido por Trefzger, que reduzir a "autoficção a simples solipsismo, em certos casos, revela uma visada crítica leviana e indigente. Sobretudo se nos deparamos com semelhante avaliação sem uma base argumentativa minimamente sólida" (TREFZGER, 2013, p. 7). Assim, parece ser mais rentável repensar a centralidade do eu na autoficção como representativa da natural constituição do sujeito, cada vez mais fragmentado. O gênero citado parece ser um dos braços direitos da modernidade na exposição e crítica do que a contemporaneidade nos traz. 
Assim, o "eu" como centro na autoficção pode ser apreendido como o reconhecimento da construção de uma identidade múltipla, forjada "pela solda de copiosos 'eus', em autêntico desalinho, posto que sem pretensão a uma síntese definitiva e estabilizadora que poria fim ao exercício performático de outrar-se" (TREFZGER, 2013, p. 8). Ao exibir-se, ao expor seu eu "mais íntimo", o "eu" esquece sua interioridade como espaço da identidade una e estável. Neste viés, o gênero autoficcional possibilita considerar o outro que habita no "eu" como um componente indissociável do sujeito em constante processo de configuração de identidade: Em Berkeley em Bellagio, o narrador eleva ao paroxismo esse acolhimento do "outro", ao afirmar: "Eu era um brasileiro a pensar em inglês o tempo todo, eu era outro em mim” (NOLL, 2003, p. 84).

A obra de João Gilberto Noll denota um indivíduo que busca incessantemente encontrar-se no mundo e em si mesmo, todavia seu "eu" se fragmenta com as relações que tece e, nestes atos, recebe características que lhe são alienígenas. A busca de seu verdadeiro "eu" encontra espaço na contemporaneidade, momento marcado por identidades fragmentadas e perpassadas por inúmeros outros. A diversidade de "outros" implica em uma pluralidade de "eus" e, neste sentido, a obra se torna sintomática de um sujeito eternamente em trânsito.

A narrativa de viagem é sintomática de tal busca, pois possibilita o olhar para o outro e para fora de si e é nesta jornada que o personagem se encontra. O final do romance mostra certa estagnação a um espaço físico, mas não representa o fim da busca pelo "eu" intrínseco. Em Berkeley em Bellagio a volta para o Brasil o situa na aceitação da incógnita de ser quem não se sabe e ao mesmo tempo no ensino de tais valores a Sarah - sua filha adotiva - que herdará suas perspectivas para lidar com os diferentes "eus".

Dentro da perspectiva proposta, a análise do texto de Berkeley em Bellagio (2002), tentou abordar características que demonstrassem a fragmentação da identidade do personagem principal. Desta forma, entendemos que a impossibilidade de criação de vínculos, a perda da memória e de sua língua materna, a relação de crise da personagem e os espaços por onde ele passou contribuem para a percepção de um sujeito não mais unificado.

Pode-se depreender que a única forma de se sentir inteiro é abraçar o outro e renegar uma visão fixa de si mesmo. Neste âmbito, o sexo, na obra, é a experimentação máxima de tal necessidade. $\mathrm{O}$ eu e o outro estão estilhaçados para fora do indivíduo e, na contemporaneidade, ganharam o mundo. Essas fronteiras deixaram há muito tempo de serem fixas, porém se misturam de tal forma que o "eu" se torna cada vez mais momentâneo, esperando o próximo vento que o torne outro.

Assim, João Gilberto Noll, ao colocar o "eu" no centro de sua narrativa, parece revelar com precisão os problemas enfrentados pelo sujeito em um mundo cada vez mais globalizado, desprovido de experiências mais profundas, sem referencialidades; bem como denuncia a ausência de uma memória confiável que acaba criando uma situação de desconforto e quebra da identidade do sujeito.

\section{Referências}

BAUMAN, Zygmunt. Modernidade líquida. Tradução de: Plínio Dentzien. Rio de Janeiro: Jorge Zahar Ed., 2001.

COMPAGNON, Antoine. O demônio da teoria: Literatura e senso comum. Tradução de: Cleonice Paes Barreto Mourão; Consuelo Fortes Santigo. 2 ed. Belo Horizonte: Editora UFMG, 2012. 
COSTA PINTO, Manuel da. “João Gilberto Noll”. In: COSTA PINTO, Manuel da. Literatura brasileira hoje. São Paulo: Publifolha, 2004.

DOUBROVSKY, Serge. "O último eu”. In: NORONHA, Jovita Maria Gerheim (org.). Ensaios sobre a autoficção. Belo Horizonte: Ed. UFMG, 2014.

HALL, Stuart. A identidade cultural na pós-modernidade. Trad. Tomaz Tadeu da Silva, Guaracira Lopes Louro. Rio de Janeiro: DP\&A, 2002.

KLINGER, Diana. Escritas de si, escritas do outro; o retorno do autor e a virada etnográfica. Rio de Janeiro: 7Letras, 2012.

KRISTEVA, Julia. Estrangeiro para nós mesmos. Rio de Janeiro: Rocco, 1994.

NOLL, João Gilberto. Berkeley em Bellagio. Rio de Janeiro: Objetiva, 2002. Lorde. Rio de Janeiro: Record, 2014.

NOLL, João Gilberto; NINA, Claudia. Entrevista ao Jornal do Brasil. 02 Nov 2002. Disponível em: < http://www.joaogilbertonoll.com.br/entrev_jb1.htm». Acesso em: 14 jul 2016.

NORONHA, Jovita Maria Gerheim (org). Ensaios sobre a autoficção. Tradução de Jovita Maria Gerheim Noronha e Maria Inês Coimbra Guedes. Belo Horizonte: Editora UFMG, 2014.

PELLEGRINI, Tânia. A imagem e a letra: aspectos da ficção brasileira contemporânea. Campinas: Mercado das Letras; São Paulo: Fapesp, 1999.

OLIVEIRA, Marcos. "Nós, poetas de nossas vidas?: desejo, homoafetividade e sujeito pós-moderno em Berkeley em Bellagio, de João Gilberto Noll”, Vivência, Natal, v. 1, n.37, p. 91-103, 2011.

TREFZGER, Fabíola Simão Padilha. "Autoficção: entre o espetáculo e o espetacular". In: XIII Congresso Internacional da Associação Brasileira de Literatura Comparada, Anais do XIII Congresso Internacional da Associação Brasileira de Literatura Comparada, Campina Grande. Campina Grande-PB: Editora Realize, 2013. v. 1. p. 1-9, 2013.

Recebido em: 12/09/2016 Aceito em: 14/11/2016

Referência eletrônica: PEREIRA, Ânderson Martins; FARIAS, Ariane Avila Neto de. Um estrangeiro de mim mesmo: a identidade fragmentada em Berkeley em Bellagio, de João Gilberto Noll. Criação \& Crítica, n. 17, p. 105-118, dez. 2016. Disponível em: 〈http:// revistas.usp.br/criacaoecriticà. Acesso em: dd mmm. aaaa. 